\title{
A Conceptual Framework to Evaluate the Environmental Sustainability Performance of Mining Industrial Facilities
}

\author{
Komninos Angelakoglou * and Georgios Gaidajis \\ Laboratory of Environmental Management and Industrial Ecology, Department of Production Engineering and \\ Management, School of Engineering, Democritus University of Thrace, 67100 Xanthi, Greece; \\ geogai@pme.duth.gr \\ * Correspondence: kangelak@pme.duth.gr; Tel.: +30-25410-79356
}

Received: 22 February 2020; Accepted: 6 March 2020; Published: 10 March 2020

check for updates

\begin{abstract}
The aim of this study is to strengthen the capacity of mining industries to assess and improve their environmental sustainability performance through the introduction of a relevant framework. Specific assessment categories and respective indicators were selected according to predefined steps. Sustainability threshold values were identified for each indicator to enable the comparison of the facility's performance with a sustainability reference value. The application of the framework results in the extraction of an Environmental Sustainability Assessment of Mining Industries Index ( $\left.\mathrm{I}_{\mathrm{ESAMI}}\right)$. The framework was applied to evaluate a mining facility in Greece, with a view to improve its applicability in parallel. The final score of environmental sustainability for the examined facility was 3.0 points ( $\mathrm{I}_{\mathrm{ESAMI}}=3.0$ points), indicating significant room for improvement where the company should aim to further enhance its sustainability performance.
\end{abstract}

Keywords: sustainability assessment; index; sustainable mining; threshold values; sustainability indicators

\section{Introduction}

Business and industrial activity are being reformed to cope with the needs and challenges of sustainable development. Environmental responsibility is moving beyond being just a legal obligation-it also stands out as a good business practice through the expansion of markets and the improvement of sales [1]. Managers face the challenge to deliver better corporate sustainability strategies [2], whereas external agents are increasingly paying attention on the concept of sustainable development [3]. While the reasoning behind the need of companies to contribute to sustainable development has been extensively analyzed in literature, relatively less progress has been made in developing integrated approaches for sustainability evaluations [4]. As a result, during the last few years, a significant number of studies attempted to strengthen sustainability evaluations at the corporate level by providing both generic and specific recommendations and guidelines [5-8].

This field of research is especially critical for mining industries which are inherently disruptive to the environment. The interdependence of mining activity and sustainable development is reflected on relevant initiatives (such as the Global Mining Initiative, Towards Sustainable Mining commitment of the Mining Association of Canada, the Sustainable Mining Initiative by Federation of Indian Mineral Industries, etc.) that attempt to set a common framework to promote responsible mining. In parallel, there is a growing interest among the academic community regarding issues associated with mining and sustainable development [9]. Mining industries usually exhibit commitment to the environment through the adoption of environmentally responsible practices [10] and sustainability reporting, with a view to balance negative impacts and reduce opposition by local communities [11]. 
Corporate sustainability reporting, especially through the adoption of the Global Reporting Initiative (GRI) guidelines, is now considered a common practice for measuring, reporting, and comparing sustainability performance [12].

Despite this background, there are many criticisms regarding the relationship between mining activity and environmental sustainability, and the literature argues that there is still significant room for improvement. Although social and environmental reporting is becoming increasingly sophisticated in the mining industry, there is a lack of uniformity that hinders the progress toward measuring corporate social responsibility and sustainable goals [13]. Belkhir et al. [14] assessed whether the GRI impacts environmental sustainability in terms of $\mathrm{CO}_{2}$ emissions and found no correlation between GRI-reporting and sustainability improvement, a result that calls for the re-examination of the effectiveness of corporate social responsibility strategies. Another issue that has been raised in the literature is the ability to compare the sustainability performance of firms, even from the same sector, which remains problematic [12]. The mining corporations' framework for measuring and reporting sustainability progress needs to be changed in order to reflect more accurate and meaningful information [15]. Tost et al. [16] argue that the mining industry is at risk of failing societal expectations regarding climate change and falling behind from other industries on natural capital considerations.

According to Lopez et al. [6], research on corporate sustainability performance need to focus on the standardization of measurements, whereas stakeholders should apply indicators measured at wider scales. It is necessary to develop and implement effective tools and methodologies to support decision making, taking into account the complexity of sustainability problems [17]. One of the biggest challenges at the moment is closing the gap between theory and practice. Despite the fact that many researchers have been working on developing sustainability assessment methods and tools, relatively few of these are applied by manufacturing companies [18].

Serving this challenge, the aim of the specific study is to provide a practical framework that is able to strengthen the evaluation and monitoring of the environmental sustainability of mining industrial facilities. The proposed framework capitalizes the results and proposals of an extensive literature review we have conducted in a previous work [19]. In this work, 48 methods were identified and clustered into six categories (individual/set of indicators, composite indices, socially responsible investment indices, material and energy flow analysis, life cycle analysis, and environmental accounting), extracting in parallel their key attributes. These categories were further evaluated based on five criteria-(a) ability to promote actions of improvement, (b) ability to help decision making, (c) potential for benchmarking, (d) applicability and ease of use, and (e) integration of wider spatial and temporal characteristics. This analysis highlighted key recommendations that can help improve the efficiency and applicability of environmental sustainability evaluations of industrial systems. More specifically, we found out that an industrial facility should be assessed both in terms of performance and concern and provide environmental sustainability threshold values for every indicator applied. An effective environmental sustainability assessment method should take into account the spatial characteristics of the examined industrial systems and assess the progress towards sustainability over time.

This paper consolidates key findings from our previous work [20-26] (i.e., proposed environmental sustainability assessment categories-building upon the principles of industrial ecology, criteria for selecting indicators to assess industrial facilities, a proposed normalization method combining categorical scale and distance to a reference), but takes one big step further by integrating all information into an applicable framework that focuses on mining industry and that was tested in a mining facility in Greece to examine its utility (closing the gap between theory and practice).

\section{Method}

The proposed framework was developed building upon a standard methodology for constructing composite indicators. A theory-driven (top-down) over data-driven (bottom-up) approach was adopted to ensure that environmental sustainability will be efficiently assessed through the selection of proper indicators. The methodology applied consists of 10 steps (Figure 1) that were defined by taking 
into account available guidelines for the construction and use of composite indicators [27] and the recommendations from the analysis of 48 sustainability assessment methods as described above [19].

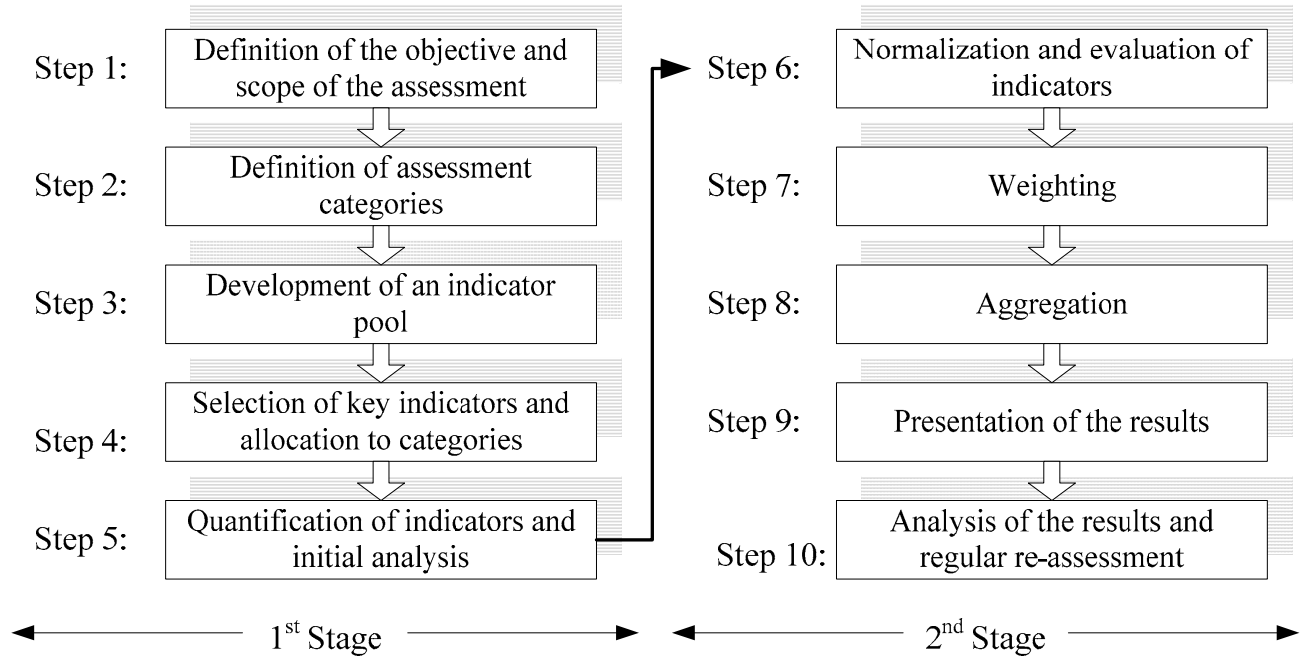

Figure 1. Methodology followed to construct the proposed assessment framework.

The 10 steps are divided into two stages of implementation in order to accommodate the gradual application of the proposed framework. The first stage comprises steps 1-5 and includes the minimum actions to be conducted by a mining industry on a facility level, who wish to acquire an initial overview of its performance related to environmental sustainability aspects. This stage is addressed to industries that have little time and resources at their disposal. The implementation of the first stage provides the data required for the assessment of the environmental sustainability. The second stage comprises the steps 6-10 and includes all actions required for the effective assessment of the environmental sustainability of the facility. The implementation of the second stage results in the development of a final comprehensive environmental score and the identification of environmental "hot spots" that call for improvement.

In the following sections, the 10 steps comprising the conceptual framework are presented. Each step contains both generic implementation guidelines and more specific instructions. Generic implementation guidelines can be used to improve existing assessment methods applied by industries, whereas specific instructions provide all the information necessary for the direct assessment of environmental sustainability. As a result, the utility of the proposed framework is twofold. It can act both as a path to develop new assessment methods (or improve existing ones) and as a ready to be used tool.

\subsection{Definition of the Objective and Scope of the Assessment}

The first step taken in order to develop the framework was to define the objective of the assessment. Indicative objectives include the identification of weaknesses and the development of improvement measures, comparison with other industrial facilities, monitoring the performance of industrial facility over time, and enhancing sustainability reports. Additionally it is necessary to define the scope of the assessment. The reference year and the boundaries of the industrial facility under examination must be selected in order to serve the objectives of the assessment. Significant factors to consider among others are the availability of data, the budget and time available to perform the assessment. The identification of the target groups to whom the results of the assessment will be addressed can further increase the effectiveness of the framework. Ecological organizations, local residents, and control bodies favor methods that follow more eco-centric approaches.

The objective of the proposed framework is to enable the evaluation and monitoring of the environmental sustainability performance of the examined facility, thus strengthening corporate 
decision making on a higher level. This choice is based on the fact that key strategic decisions on sustainability-related issues are mostly taken on an upper-management level. The full implementation of the proposed framework is addressed primarily to mining industrial facilities that are already in operation. The scope of the assessment includes the whole supply chain from raw material extraction to final processing (cradle to gate approach). This approach is essential to capture environmental impacts deriving from different life cycle stages of the operation of the examined facility. The time reference for the assessment is one year (annual implementation/results) to serve compatibility with annual reports and facilitate data mining.

The reason for conducting the assessment on the industrial facility level (rather than corporate level) is that it enables the identification of unsustainable industrial processes/practices at the source while taking into account specific spatial characteristics of the facility under examination. Consequently, the results of the assessment are expected to better facilitate decision making and the identification of amelioration actions. The proposed methodology is focusing at the moment only on the environmental aspect of sustainability but can be adapted to include economical and social aspects.

\subsection{Definition of Assessment Categories}

The next step was to identify various sub-categories that compose the examined phenomenon, which in our case is environmental sustainability [27]. In other words, the parameters need to be considered for efficiently assessing the environmental sustainability of the system under examination had to be identified. Sustainability assessments should be based on certain principles to enhance their effectiveness [28]. Additionally, every sub-category must have a clear purpose that serves the goal of the evaluation. To ensure that the most important issues in terms of environmental sustainability will be assessed, the principles of industrial ecology (IE) were utilized to develop the specific framework. The authors have summarized and examined the principles of IE in a previous work [21]. Additionally, the environmental assessment categories proposed by the Global Reporting Initiative [15] and further recommendations by mining experts were taken into account. As a result of this process, a list of eight key categories to assess the environmental sustainability was developed (Table 1).

Table 1. Proposed environmental sustainability assessment categories.

\begin{tabular}{cc}
\hline S/N & Name of the Assessment Category \\
\hline 1 & Mineral resources and materials \\
2 & Emissions and waste \\
3 & Energy and water \\
4 & Suppliers and environmental performance \\
5 & Biodiversity \\
6 & Land use and rehabilitation \\
7 & Impact on the environmental and climate change \\
8 & Impact on human health \\
\hline
\end{tabular}

\subsection{Development of an Indicator Pool}

Following the definition of assessment categories, an indicator pool was developed including indicators that can potentially be utilized to assess the eight environmental sustainability categories. A filtering procedure according to predefined criteria was undertaken to narrow down the vast number of potential indicators that can be included in the pool [29]. Two screening criteria were selected by the authors in order to identify potential indicators that can be utilized in the proposed framework-(a) the indicator must be included in at least one of the available environmental sustainability methods reviewed [19] and (b) the indicator must satisfy the principles of IE to ensure that sustainable actions highlighted by IE will be promoted [22]. According to that criteria set, we developed a list of 108 indicators. Indicators with similar name or common indicators expressed in different units appear once in the list so the actual number of indicators analyzed is much higher. 


\subsection{Selection of Key Indicators and Allocation to Categories}

The final key indicators to be integrated into the framework were selected from the pool with the application of five criteria [26] — (a) be easily understandable to various stakeholders, (b) be easily measured and are cost-effective in terms of data collection, (c) can cover long-term issues and be applied in multiple scales, (d) support decision making and promote desired behavior, and (e) be potentially comparable. All indicators included in the indicator pool (Step 3) were ranked according to these criteria with the utilization of a $0-4$ scoring scale per criterion, resulting in a final score from $0-20$ points per indicator (where 20 indicates maximum performance). The indicators were scored by a panel of five experts from both academia and industry. The analytical process followed to select the final core indicators is the following:

1. Distribution of the indicators included in the indicator pool to one of the eight proposed assessment categories.

2. Selection of the indicators with the highest score. In case two indicators served the same purpose, the one with the highest score was selected. Extra care was given to not include indicators that assess the same environmental parameter (double counting).

3. Configure, if necessary, the scope and the unit of measurement of indicators in order to improve the effectiveness of evaluation and comply with the principles of sustainable development. In many cases, absolute units (e.g., kWh consumed) had to be altered into relative ones (e.g., $\mathrm{kWh}$ consumed per tons of product) to strengthen decision making.

4. Consultation with the environmental department of the mining facility selected as a case study (see Section 3) to implement the proposed framework. In this way, indicators that present a particular interest for the mining facility have been integrated or excluded by the framework.

Resulting from this process, 19 final core indicators of environmental sustainability were selected that constitute the basis of the proposed framework (Table 2). The fact that the indicators were selected according to a structured and clear process increases the efficiency of the evaluation and ensures that most important parameters in terms of environmental sustainability are measured without increasing too much the time and resources required for the implementation. However, additional case specific indicators may be integrated by the user, if deemed necessary.

\subsection{Quantification of Indicators and Initial Analysis}

During this step, the evaluator must collect all data needed for the efficient quantification of the indicators and perform an initial analysis of the results. The initial analysis should include a validity check in order to examine whether the indicator values are reasonable and identify any errors in data collection [24]. If data are available from previous years, comparing the results and trying to justify differences is encouraged. In Section 3, the framework was implemented in a mining facility in order to examine its applicability and usefulness.

\subsection{Normalization and Evaluation of Indicators}

Normalization of indicators is necessary if we want to proceed to data aggregation [30]. Indicators above or below the mean, min-max, z-score, distance to a reference, and categorical scales are some examples of the normalization methods available [27]. A sensitivity analysis of normalization methods indicated that the distance to a reference method is the most suitable choice for sustainability performance evaluations in industry [30]. Based on this finding, we propose a hybrid normalization procedure, combining the categorical scale and the distance to a reference approaches. Distance to a reference is applied to compare the value of an indicator to a reference value whereas categorical scale assigns a score to every indicator using a numerical or qualitative scale. The same approach has been successfully applied to normalize and assess key indicators utilized for the evaluation of sustainable water consumption and management of industrial facilities [26]. 
Table 2. Final core environmental sustainability indicators selected to be included in the framework (ENi: EN stands for environmental, whereas $i$ is the serial numbering).

\begin{tabular}{|c|c|}
\hline $\mathrm{S} / \mathrm{N}$ & Name of Indicator \\
\hline EN1 & $\begin{array}{c}\text { Category 1: Mineral resources and materials } \\
\text { Total consumption of resources and materials and quantity of products produced (in absolute and } \\
\text { relative units) }\end{array}$ \\
\hline EN2 & $\begin{array}{l}\text { Utilization of mining waste } \\
\text { Category 2: Emissions and waste }\end{array}$ \\
\hline EN3 & Air emissions by type and total (in absolute and relative units) \\
\hline EN4 & Liquid waste by type and total (in absolute and relative units) \\
\hline EN5 & Mining waste to be deposited by type and total (in absolute and relative units) \\
\hline EN6 & $\begin{array}{l}\text { Category 3: Energy and water } \\
\text { Energy consumption by type and total (in absolute and relative units) }\end{array}$ \\
\hline EN7 & Total industrial water consumption (in absolute and relative units) \\
\hline EN8 & Percentage of water that is recycled or reused as compared to total consumption \\
\hline EN9 & Availability of water resources at local level \\
\hline EN10 & $\begin{array}{l}\text { Category 4: Suppliers and environmental performance } \\
\text { Environmental assessment of suppliers and contractors }\end{array}$ \\
\hline EN11 & Initiatives to enhance environmental performance, accountability and equity \\
\hline EN12 & $\begin{array}{l}\text { Category 5: Biodiversity } \\
\text { Numbers of species included in the IUCN red list or national lists of protected species and are } \\
\text { affected by the facility's activities, classified by the level of extinction risk }\end{array}$ \\
\hline EN13 & Identification and mitigation actions on biodiversity \\
\hline EN14 & $\begin{array}{l}\text { Category 6: Land use and rehabilitation } \\
\text { Total area restored to total disruption }\end{array}$ \\
\hline EN15 & $\begin{array}{c}\text { Category 7: Impact on the environment and climate change } \\
\text { Global warming potential }\end{array}$ \\
\hline EN16 & Number and description of environmental accidents \\
\hline EN17 & Hazard risk of utilized materials, emissions and waste \\
\hline EN18 & $\begin{array}{l}\text { Category 8: Impact on human health } \\
\text { Ambient air quality of the industrial site }\end{array}$ \\
\hline EN19 & Risk of failure of infrastructure \\
\hline
\end{tabular}

The reference value serves as the starting criterion to assign sustainability scores with the application of a 5-point semi-qualitative scale (Very High (5), High (4), Medium (3), Low (2), and Very Low (1)). Specific sustainability reference values were identified for each indicator to enable the comparison of the examined industry's performance with a sustainability reference point (see Appendix A). In our case, sustainability reference values reflect (a) either target values set by EU or international organizations, (b) either values derived from the analysis of the performance of international mining projects, (c) either expert's estimations and proposals from international scientific literature, or (d) either corporate objectives.

The pros and cons of the proposed normalization procedure were summarized and are presented in Table 3. The identification of commonly accepted reference values for every indicator was found to be a time and effort intensive process especially for uncommon indicators. To cope with this challenge, internal targets and expert judgments can be applied until a more concrete reference value is available. These targets must be evaluated and modified regularly to reduce subjectivity. The basic goal of the specific procedure is to aggregate indicators into one single sub-index. Loss of information during normalization can be balanced if the initial analysis (Step 5) has been carefully conducted [24]. 
Table 3. Pros and cons of the proposed normalization method [23].

\begin{tabular}{|c|c|}
\hline Pros & Cons \\
\hline $\begin{array}{l}\text { + Enables the aggregation of indicators into a composite } \\
\text { environmental sustainability index while in parallel } \\
\text { reflecting a distance from an environmentally sustainable } \\
\text { performance per indicator. } \\
\text { + It can assess both quantitative and qualitative indicators. } \\
\text { + The process of finding a reference point generates value } \\
\text { in terms of environmental sustainability knowledge. } \\
\text { + No extensive data for a great number of industries } \\
\text { and/or data over many consecutive years are required in } \\
\text { contrast with common normalization methods. } \\
\text { + Results are easily apprehendable, even by non-experts. } \\
\text { + "Best in class" industry still receives a better score than } \\
\text { other industries but not necessarily the maximum score if } \\
\text { the sustainability criteria are not met. } \\
+ \text { If common indicators and respective reference points } \\
\text { are applied, it can be used to benchmark the } \\
\text { environmental sustainability performance of } \\
\text { different facilities. }\end{array}$ & $\begin{array}{l}\text { - The process of finding well accepted reference } \\
\text { points for every indicator is time and effort intensive. } \\
\text { - A lot of information is lost due to the fact that a } \\
\text { discrete five-point scale is applied, which may lead to } \\
\text { accumulation of scores into the same cluster (many } \\
\text { industries with the same score). } \\
\text { - The selection of a reference point and a scoring scale } \\
\text { entails significant level of subjectivity (thus } \\
\text { uncertainty of the results). } \\
\text { - It may be too hard for industries to gain a high score } \\
\text { during the first years of implementation. }\end{array}$ \\
\hline
\end{tabular}

\subsection{Weighting}

Weighting (expression of how important is a parameter compared to another) is a particularly significant step during the development of a composite indicator [31]. As in the case of a normalization process, there is not a commonly accepted way of data weighting [32]. Weights selected by the analyst is not necessarily a bad practice; however, it is very likely to have negative consequences regarding the acceptance of the results [33]. On the other hand, weights result from statistical methods, may be even less acceptable from the perspective of decision-making and policy development toward sustainability, as insignificant political parameters can receive high scores, while innovative approaches on sustainable development may not even taken into consideration [32].

In the proposed framework, we suggest equal weights to be attributed to all indicators and assessment categories. The specific decision is based on two basic reasons. The indicators of the framework were selected using a concrete procedure to ensure that key environmental issues are examined with maximum efficiency. Every indicator serves a different aspect of environmental sustainability, and all issues must be taken into account if we want to move towards sustainable development. Equal weights discourage industries from merely focusing on the improvement of the indicators with the higher weights. This approach serves better the sustainability notion according to which the performance of a system should be assessed taking into account various parameters (holistic approach). Second, it should be taken into account that the proposed framework attempts to assess industrial facilities regardless their special characteristics (e.g., size). If weights were to be adopted, these would have to be adapted to specific types, sizes, and spatial characteristics of the facility, which would significantly increase the complexity and uncertainty of the results, especially if used for benchmarking purposes.

\subsection{Aggregation}

The utilization of a high number of indicators might be problematic for the efficient communication of the environmental sustainability to the senior management of the industry and the general public. Since all indicators are expressed in a common quantitative scale (1-5 points), the extraction of individual sub-indices, and a final single index of environmental sustainability is possible. More specifically, by applying the proposed framework, the following environmental sustainability scores can be extracted:

- Per assessment category-Eight sub-indices: 
I1: Mineral resources and materials index

I2: Emissions and waste index

I3: Energy and water index

I4: Suppliers and environmental performance index

I5: Biodiversity index

I6: Land use and rehabilitation index

I7: Impact on the environmental and climate change index

I8: Impact on human health index

- Total- One final index of environmental sustainability:

I $\quad \mathrm{I}_{\mathrm{ESAMI}}$ : Environmental Sustainability Assessment of Mining Industries index

The sub-indices per assessment category result from the average score of the indicators that compose the category:

$$
\mathrm{I}_{\mathrm{X}}=\frac{\sum_{i=1}^{n} w_{i}}{n},
$$

where $\mathrm{x}$ is the examined category $(x \in \mathbb{Z}\{1, \ldots, 8\}), \mathrm{w}_{\mathrm{i}}$ is the score of the indicator $\mathrm{i}$, and $\mathrm{n}$ is the number of indicators included in the assessment category $x$. Sub-indices Ix can help industries identify and analyze those categories where there is a great potential for improving their environmental sustainability. The final index of environmental sustainability is estimated from the average score of the eight assessment categories:

$$
\mathrm{I}_{\mathrm{ESAMI}}=\frac{\sum I_{X}}{8} \text { where } x \in \mathbb{Z}\{1, \ldots, 8\} .
$$

The extraction of a final overall score enables the efficient communication of the results and comparison with other facilities provides an overview of the environmental sustainability of the examined facility and allows the regular re-evaluation of the progress achieved through the years.

\subsection{Presentation of the Results}

The presentation of the results is an issue that should not be neglected and depends on many factors such as the target audience [34]. The proposed framework provides significant feedback (indicators utilization, extraction of sub-indices, finding reference values, quantitative scores, etc.) for the efficient presentation of the results. A number of key techniques for enhancing the presentation of the results include: the development of summarized tables of results, the development of trend charts per indicator for consecutive years, the development of graphs depicting the scores per sub-indices, the presentation of key results to websites, leaflets, and others. The results from the implementation of the framework could serve as an important means of strengthening sustainability reports, corporate social responsibility reports, environmental impact studies, and relevant presentations at meetings and conferences.

\subsection{Analysis of theRresults and Regular Re-Assessment}

The final step refers to the analysis and interpretation of the results. The analysis of the results is the step with the highest impact on the facility under examination since their interpretation will lead to successful decision making and the formulation of strategies for improving environmental sustainability. Consequently it should be performed with great attention. A successful analysis of results should be able to answer the following key questions:

Analysis per assessment category: Which categories present the lowest score and what factors (indicators) caused this? In this case it is particular useful to return to the results of step 5 in order to explore in greater depths the indicators that received the lowest scores. 
Total analysis: What is the final score of environmental sustainability and how it can be improved? The conduction of a sensitivity analysis to quantify the alternative actions of improvement is highly encouraged at this stage. For the easier analysis of the results, the following general rule of interpretation is proposed depending on the rating of the index:

- Score: 1-1.5 points: very low sustainability performance

- Score: $1.5-2.5$ points: low sustainability performance

- Score: $2.5-3.5$ points: moderate sustainability performance

- Score: $3.5-4.5$ points: high sustainability performance

- Score: $4.5-5$ points: very high sustainability performance

As already mentioned, the utility of the proposed framework is twofold. It can act both as a path to develop new assessment methods (or improve existing ones) and as a ready to be used tool by industries who wish to assess their environmental sustainability. In the second case, the user can utilize the analytical results of the implementation of each step described before (proposed assessment categories, indicator pool, implementation guide, core indicators etc.). In this way, industries only need to apply steps $1,5,6,8,9$, and 10 , which reduces the time and cost of implementation.

\section{Case Study—Evaluation of a Mining Facility in Greece}

The proposed framework was implemented in a mining industrial facility in Greece in order to examine its applicability and usefulness. The system under examination was selected with a view to represent facilities of relatively high complexity of material and energy balances and significant environmental concerns. The steps described in the previous section were applied by taking into account the following assumptions.

The objective defined was to assess the overall environmental sustainability performance (current state of operation) and identify key weak spots that call for improvement. The scope of the assessment included the entire mining and metallurgical installations of the mines in the area that were examined as an entity to reflect the overall sustainability performance of the mining activity of the company.

The environmental sustainability performance was assessed using the eight proposed thematic categories and the 19 core environmental sustainability indicators of the framework. Indicators EN3, EN4, and EN19 were not evaluated due to the lack of relevant data because the facility was in the process of developing the necessary procedures for their quantification during the conduction of this study.

The data required for the assessment of each indicator were acquired from the following sources: a) published sustainability reports of the company, b) published data from the Association of Mining Enterprises in Greece, c) raw data from the environmental monitoring program of the company, and d) published data from technical reports and Environmental Impact Assessment studies. The normalization and evaluation of the indicators was carried out using the proposed method and respective sustainability reference values presented in Appendix A. It was further decided that all indicators and categories are of the same significance (no weights were attributed). Specific data and calculations will not be presented in detail due to confidentiality reasons and space restrictions. For a better understanding of the results though, a number of particular features of the case study are clarified below that have significantly influenced the evaluation.

A number of sites within the facility were still under development and/or at the stage of preparing the start of production, resulting in the consumption of high quantities of raw materials, energy, and water without the corresponding production of marketable products. That led to an abnormal correlation between the quantity of run of mine (ROM) ore and the marketable products with the inputs (raw materials, energy, water) and outputs (gaseous emissions, liquid waste, solid waste). As a result, indicators assessed in relative units (per ton of ROM ore) exhibited low or very low performance even when there has been an annual reduction in absolute terms. Typical examples are the indicators EN5, EN6, and EN15 related to the deposition of mining waste, energy consumption and global 
warming potential respectively. The production process is expected to be normalized during the full development of the examined facility, and thus, the assessment will better capture the efforts of the company to improve its sustainability performance.

\subsection{Results PerIindicator and Assessment Category}

The results per indicator and per assessment category are summarized in Table 4 and Figure 2 respectively. The score of the assessment categories ranged from $1.0\left(\mathrm{I}_{2}\right.$-missions and waste) to 5.0 points ( $\mathrm{I}_{8}$-human health impacts) exhibiting a noticeable fluctuation per indicator and category. The case study received the highest score in 6 out of 16 indicators evaluated (indicators 2, 8, 11, 13, 16, and 18) and the minimum score to 6 (indicators 1, 5, 6, 7, 12, and 15). The peculiarities of the year of examination, discussed in the previous section, do not allow the extraction of safe conclusions for the assessment categories $\mathrm{I}_{1}, \mathrm{I}_{2}$, and $\mathrm{I}_{3}$. It is characteristic that for the specific year, the mass balance of inputs and outputs was negative while the output intensity (tons of outputs produced per ton of ROM ore mined) was higher than that input intensity (tons of inputs consumed per ton of ROM ore mined).

Table 4. Environmental sustainability performance per indicator.

\begin{tabular}{|c|c|c|c|}
\hline $\mathbf{S} / \mathbf{N}$ & Name of indicator & Performance & Score \\
\hline EN1 & $\begin{array}{l}\text { Category 1: mineral resources and materials } \\
\text { Total consumption of resources and materials and quantity of } \\
\text { products produced }\end{array}$ & Very Low & 1.0 \\
\hline EN2 & $\begin{array}{l}\text { Utilization of mining waste } \\
\text { Score of Category 1: }\end{array}$ & Very High & $\begin{array}{c}5.0 \\
3.0 / 5.0\end{array}$ \\
\hline \multirow{5}{*}{$\begin{array}{l}\text { EN3 } \\
\text { EN4 } \\
\text { EN5 }\end{array}$} & Category 2: emissions and waste & \multirow{5}{*}{$\begin{array}{l}\text { No data available } \\
\text { No data available } \\
\text { Very Low }\end{array}$} & \\
\hline & Air emissions by type and total & & \\
\hline & Liquid waste by type and total & & \\
\hline & 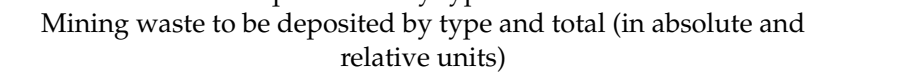 & & 1.0 \\
\hline & Score of Category 2: & & 1.0/5.0 \\
\hline \multicolumn{4}{|c|}{ Category 3: energy and water } \\
\hline EN6 & Energy consumption by type and total & Very Low & 1.0 \\
\hline EN7 & Total industrial water consumption & Very Low & 1.0 \\
\hline EN8 & $\begin{array}{l}\text { Percentage of water that is recycled or reused as compared to total } \\
\text { consumption }\end{array}$ & Very High & 5.0 \\
\hline EN9 & $\begin{array}{c}\text { Availability of water resources at local level } \\
\text { Score of Category 3: }\end{array}$ & Moderate & $\begin{array}{c}3.0 \\
2.5 / 5.0\end{array}$ \\
\hline \multicolumn{4}{|c|}{ Category 4: suppliers and environmental performance } \\
\hline EN10 & Environmental assessment of suppliers and contractors & Moderate & 3.0 \\
\hline EN11 & $\begin{array}{c}\text { Initiatives to enhance environmental performance, accountability and } \\
\text { equity }\end{array}$ & Very High & 5.0 \\
\hline & Score of Category 4: & & $4.0 / 5.0$ \\
\hline EN12 & $\begin{array}{l}\text { Category 5: biodiversity } \\
\text { Numbers of species included in the IUCN red list or national lists of } \\
\text { protected species and are affected by the facility's activities, classified } \\
\text { by the level of extinction risk }\end{array}$ & Very Low & 1.0 \\
\hline EN13 & $\begin{array}{l}\text { Identification and mitigation actions on biodiversity } \\
\text { Score of Category 5: }\end{array}$ & Very High & $\begin{array}{c}5.0 \\
3.0 / 5.0\end{array}$ \\
\hline EN14 & $\begin{array}{l}\text { Category 6: land use and rehabilitation } \\
\text { Total area restored to total disruption } \\
\text { Score of Category } 6 \text { : }\end{array}$ & Low & $\begin{array}{c}2.0 \\
2.0 / 5.0\end{array}$ \\
\hline \multicolumn{4}{|c|}{ Category 7: impact on the environment and climate change } \\
\hline EN15 & Global warming potential & Very Low & 1.0 \\
\hline EN16 & Number and description of environmental accidents & Very High & 5.0 \\
\hline EN17 & Hazard risk of utilized materials, emissions and waste & High & $4.0 / 5.0$ \\
\hline & Score of Category 7: & & $3.3 / 5.0$ \\
\hline \multicolumn{4}{|c|}{ Category 8: impact on human health } \\
\hline EN18 & Ambient air quality of the industrial site & Very High & 5.0 \\
\hline EN19 & Risk of failure of infrastructure & \multicolumn{2}{|c|}{ No data available } \\
\hline & Score of Category 8: & & $5.0 / 5.0$ \\
\hline & Total Environmental Sustainability Score I (ESAMI): & & $3.0 / 5.0$ \\
\hline
\end{tabular}




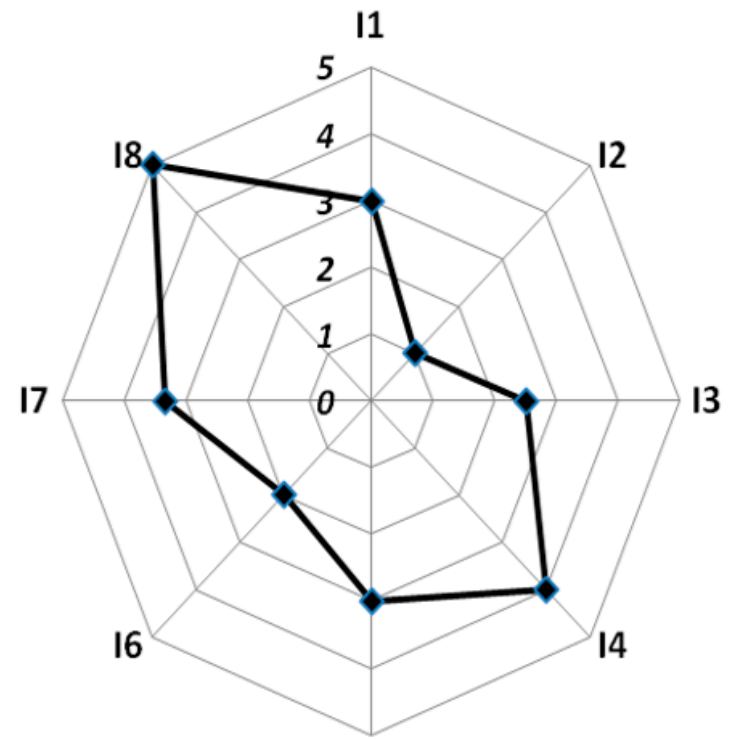

15

\begin{tabular}{|cc|}
\hline $\mathrm{I}_{1}$ & Mineral resources and materials \\
$\mathrm{I}_{2}$ & Emissions and waste \\
$\mathrm{I}_{3}$ & Energy and water \\
$\mathrm{I}_{4}$ & Suppliers and environmental performance \\
$\mathrm{I}_{5}$ & Biodiversity \\
$\mathrm{I}_{6}$ & Land use and rehabilitation \\
$\mathrm{I}_{7}$ & Impact on the environmental and climate change \\
$\mathrm{I}_{8}$ & Impact on human health \\
\hline
\end{tabular}

Figure 2. Environmental sustainability performance per category.

The examined facility is characterized by very high rates of recovery/reuse of mining waste $(\mathrm{EN} 2=5.0$ points) and water (EN8 $=5.0$ points), thus balancing the negative impact of development and restoration works during this stage. The facility management has undertaken a significant number of initiatives to enhance its environmental performance, accountability and equity, whereas takes into account the environmental performance of its contractors $\left(\mathrm{I}_{4}=4.0\right.$ points), supporting the view that industries with particular environmental concerns and pressures, tend to account more on environmental management related issues.

The facility is characterized by moderate performance regarding biodiversity protection $\left(\mathrm{I}_{5}=3.0\right.$ points). The high concern due to the significant biodiversity of the area (EN12 $=1.0$ points) is offset by mitigation actions on biodiversity (EN13 $=5.0$ points) as the company has taken a significant number of relevant initiatives in line with best available practices for biodiversity protection. At this stage (development of sub-projects), the case study is characterized by low performance in land use and rehabilitation $\left(\mathrm{I}_{6}=2.0\right.$ points $)$ as the majority of the disturbed area has not been restored. The score in the specific category is expected to improve over time as rehabilitation works are in progress.

The assessment categories related to environmental and climate change impacts ( $I_{7}=3.3$ points) and human health impacts $\left(\mathrm{I}_{8}=5.0\right.$ points) exhibited moderate and very high performance respectively. This result indicates that the operation of the facility affects the environment and human health in an acceptable way, in case an environmental accident does not occur. An exception is indicator EN15 regarding global warming potential, which received a minimum score as the equivalent carbon dioxide emissions are calculated on the basis of the energy consumption per ton of ROM ore. Carbon dioxide emissions in absolute units $(\approx 57,000$ tons) are at normal levels for heavy industries and much lower that energy and chemical industries. Reagents utilized in the production process, although mostly 
hazardous, represent a very small proportion of the overall input-output balance and with proper management the risk of large-scale accidents is minimized. On the contrary, the produced products and materials left over after the separation process present a significant risk due to the combination of their quantities and risk.

\subsection{Total Results - The IESAMI Index}

According to the results from the implementation of the proposed framework, the final score of environmental sustainability for the examined facility was 3.0 points ( $\mathrm{I}_{\mathrm{ESAMI}}=3.0$ points). The score is considered satisfactory (moderate environmental sustainability) if we take into account the fact that the system under examination is characterized by very high environmental and social concerns and the particularities of the operation phase during the assessment year.

The minimization of environmental impacts is one of the biggest challenges of the mining industry. The proposed framework follows a more eco-centric approach according to which the facility examined should continually improve the efficiency of its processes, set long-term goals (e.g., complete land rehabilitation), and take into account concerns in which one cannot directly intervene (e.g., biodiversity of the area, availability of water in the area, etc.).

The assessment and analysis of the core indicators indicated significant room for improvement where the company should aim to further enhance its sustainability performance. A number of suggestions have been developed taking into account the possible ways to increase the score of the indicators with the lowest performance.

- Reduce solid waste deposited annually by finding ways to exploit/reuse them and/or innovative techniques for their management.

- Strengthen energy saving efforts and reduce the dependency on utilization of oil. In this context, a) examine the viability of meeting specific energy needs (e.g. offices) using renewable energy sources, b) place simple control and energy saving mechanisms (e.g. sensors, photocells, led lighting), and c) continuously monitor energy management and consumption indicators.

- Continuously monitor indicators on water management/consumption and the elaboration of an analytical water balance for each sub-project within the facility and as a whole.

- Develop concrete procedures for the environmental assessment of the suppliers.

- Develop concrete procedures for estimating the risk of failure of infrastructures.

The structure of the framework and the assessment process presented a high level of flexibility that allowed its implementation with minimum resources and time available. Thus, one of the key objectives of the framework which is providing scalable levels of difficulty was achieved, thus allowing facilities of varying capacity to be able to implement it.

The procedure of quantifying and scoring some of the indicators presented great added value for the facility since, in several cases, it raised issues (and respective concerns) that were not taken into account until then. The need to develop analytical balances of materials/energy/water/waste and the extraction of composite indicators provided a general overview of the environmental performance of the facility, indicating areas of high concern. The complete implementation of the framework required the cooperation of different sections of the industry something that helps to detect broader issues and data gaps. Results obtained during the implementation of the steps could be used in parallel with the development/update of sustainability and corporate responsibility reports.

\section{Concluding Remarks and Future Research}

This study introduced a conceptual framework that is able to strengthen the evaluation and monitoring of the environmental sustainability of mining industrial facilities. The framework can be either utilized as a guide by industries who wish to enhance the way they assess environmental sustainability issues and/or as a stand-alone tool of assessment. It consists of 10 well-defined steps that include specific guidelines and tips that allow for its gradual implementation. 
The framework attempts to adopt a more proactive approach, aiming to assess the actions that lead to reduced/increased environmental impact rather than the impacts themselves. The specific approach strengthens the probability that the results will be accepted from external relevant agents and auditors. The framework covers environmental issues in a wider spatial and temporal frame in accordance with the targets of sustainable development.

The reason for conducting the assessment on the industrial facility level (rather than corporate level) is that it enables the identification of unsustainable industrial processes at the source while taking into account specific spatial characteristics of the facility under examination. Consequently, the results of the assessment are expected to better facilitate the identification of amelioration actions. The proposed methodology is focused at the moment only on the environmental aspect of sustainability but can be adapted to include the economic and social aspects.

Linking environmental sustainability indicators to a sustainability reference point can provide a meaningful sustainability performance based on a distance-to-target approach. To cope with this challenge, a hybrid normalization procedure combining the categorical scale and the distance to a reference approach was introduced in the framework. The combination of these two methods enables the aggregation of indicators into a composite environmental sustainability index, whereas in parallel, it reflects a distance from an environmentally sustainable performance-target per indicator. These targets (and thus the assessment of the industry) must be re-evaluated and modified regularly due to the dynamic nature of environment.

The implementation of the proposed methodological framework indicated a number of particular points of interest that can further enhance its applicability. The categories that were harder to be assessed (in terms of data and time needed) were Category 1: mineral resources and materials and Category 2: emissions and waste. The development of an analytical input-output inventory and its reduction in the same units entails the conduction of transformations that can complicate the calculations and affect the reliability of the results. Therefore, it is particular useful to develop a conversion factor inventory to ensure reliable estimations. Despite the effort to minimize the data required for the assessment, the framework still requires information related to a number of different activities within the facility. The development of a standardized data acquisition form will reduce the time of implementation and will facilitate the exchange of information among the various departments of the facility.

The authors are planning to continuously improve the effectiveness of the proposed framework by updating sustainability reference points and developing supporting software that will enable its fast and reliable implementation. Additionally the framework should be implemented into a significant number of industrial facilities. The specific feedback will provide the opportunity to examine issues such as the framework's ability to predict future performance and concerns and the examination of interrelations among the proposed indicators. Other key issues that need to be examined in the future include the potential usability of the framework to assess economic and social aspects of sustainability, its combination with other methods to assess different types of systems, and its applicability to develop relevant sustainability eco-labeling schemes.

Industries and organizations in general will be expected to assess and report their environmental sustainability in the near future. The ideas and steps described in this study can help in developing a common methodological framework that can be applied by mining industries and promote environmental sustainability.

Author Contributions: All authors contributed equally to the text. All authors have read and agreed to the published version of the manuscript

Funding: This research received no external funding.

Conflicts of Interest: The authors declare no conflict of interest. 


\section{Appendix A}

Table A1. Normalization and assessment procedure per indicator included in the proposed framework.

\begin{tabular}{|c|c|c|c|}
\hline Indicator & Calculation & $\begin{array}{l}\text { Identification of a Sustainability } \\
\text { Reference Value }\end{array}$ & Normalization and Assessment \\
\hline $\begin{array}{l}\text { EN1 } \\
\text { Total consumption of } \\
\text { resources and materials } \\
\text { and quantity of products } \\
\text { produced }\end{array}$ & $\begin{array}{l}\text { (1) Calculation and recording of all inputs necessary for the production process (water and fuels not } \\
\text { included); } \\
\text { (2) Convert all inputs to a common unit of measurement and sum up results; } \\
\text { (3) Define a functional unit (tons of run of mine (ROM) ore is proposed); } \\
\text { (4) Divide total input consumption with functional unit and find resource/material intensity; } \\
\text { (5) Repeat steps 1-4 for outputs (including products) to find output intensity and examine mass balance } \\
\text { (inputs-outputs). }\end{array}$ & $\begin{array}{l}\text { An annual reduction of resource/material } \\
\text { intensity over } 2 \% \text { can be set as a reference } \\
\text { value for VH sustainability (and/or a total } \\
\text { reduction of over } 20 \% \text { in comparison with a } \\
\text { past reference year). These values were } \\
\text { selected taking into account EU's targets for } \\
\text { strengthening resource efficiency in } \\
\text { industries by } 2030 \text { [35]. }\end{array}$ & 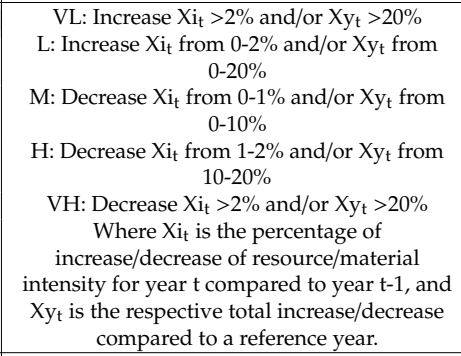 \\
\hline $\begin{array}{l}\text { EN2 } \\
\text { Utilization of mining } \\
\text { waste }\end{array}$ & $\begin{array}{c}\text { Reuse percentage is calculated according to the following formula } \\
\text { Tailings }+ \text { WR (reused) } \\
\text { ROM+WR-concentrates produced } \% \\
\text { WR: Waste Rock }\end{array}$ & $\begin{array}{l}\text { Mining waste reuse over } 40 \% \text { can be set as a } \\
\text { reference value for VH sustainability. This } \\
\text { percentage assures the significant reduction } \\
\text { of tailings and rock waste disposal; whereas } \\
\text { the target value can be achieved since the } \\
\text { company can use tailings/rock wastes of } \\
\text { previous years. }\end{array}$ & $\begin{array}{c}\mathrm{VL}: \mathrm{X}_{\mathrm{i}_{\mathrm{t}} \leq 10 \%} \\
\mathrm{~L}: 10 \%<\mathrm{Xi}_{\mathrm{i}} \leq 20 \% \\
\mathrm{M}: 20 \%<\mathrm{X}_{\mathrm{i}_{t}} \leq 30 \% \\
\mathrm{H}: 30 \%<\mathrm{X}_{\mathrm{i}_{t}} \leq 40 \% \\
\mathrm{VH}: \mathrm{X}_{\mathrm{i}_{\mathrm{t}}}>40 \% \\
\text { Where } \mathrm{X}_{\mathrm{i}_{\mathrm{t}}} \text { is the percentage of reuse of mining } \\
\text { waste for year t. }\end{array}$ \\
\hline $\begin{array}{l}\text { EN3 } \\
\text { Air emissions by type } \\
\text { and total }\end{array}$ & $\begin{array}{l}\text { Dust emissions and intensity of dust emissions in the atmospheric environment are calculated according to } \\
\text { the formulas } \\
\text { - Dust emissions in the air (ton) }=\mathrm{Ci} \times \mathrm{Ri} \times \mathrm{Oi} \\
\text { - Intensity }(\mathrm{g} / \text { ton })=\text { Dust emission in the air } / \mathrm{ROM} \text { ore } \\
\text { where } \\
\text { C: average concentration }\left(\mathrm{mg} / \mathrm{m}^{3}\right) \\
\text { R: average emission rate from the source }\left(\mathrm{m}^{3} / \mathrm{hr}\right) \\
\text { O: unit operation time (hrs) } \\
\text { i: year under examination }\end{array}$ & $\begin{array}{l}\text { An annual reduction of dust emissions } \\
\text { intensity over } 2 \% \text { can be set as a reference } \\
\text { value for VH sustainability (and//or a total } \\
\text { reduction of over } 20 \% \text { in comparison with a } \\
\text { past reference year). These values were } \\
\text { selected in accordance with EN1 indicator } \\
\text { target values for the reduction of } \\
\text { inputs/outputs and are taking into account } \\
\text { the strategic } 40 \% \text { target value for the } \\
\text { reduction of greenhouse gases of EU } \\
\text { until } 2030 \text {. }\end{array}$ & 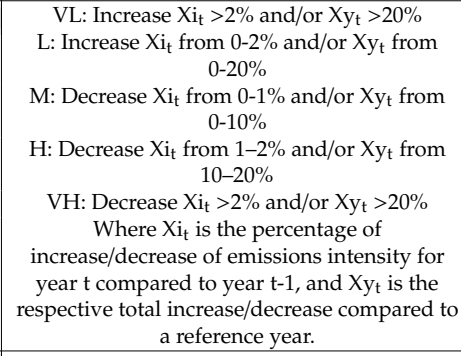 \\
\hline $\begin{array}{l}\text { EN4 } \\
\text { Liquid waste by type } \\
\text { and total }\end{array}$ & $\begin{array}{l}\text { The total amount of water pollutants is calculated according the following formula: } \\
\qquad \begin{array}{c}\text { Total pollution load }=\sum_{\mathrm{i}=1}^{\mathrm{i}=\mathrm{n}} \mathrm{Ci} \times \mathrm{Q} \\
\text { Where: }\end{array} \\
\begin{array}{c}\text { C: average concentration of pollutant in the treated effluent discharged to a natural receiver (sea, river, lake, } \\
\text { etc. in } \mu \mathrm{g} / \mathrm{m}^{3} \text { ) }\end{array} \\
\text { Q: volume of treated effluent discharged to natural receivers }\left(\mathrm{m}^{3}\right) \\
\text { i: pollutant } \\
\text { n: number of pollutants under examination }\end{array}$ & $\begin{array}{l}\text { An annual reduction of pollutant load } \\
\text { discharged to natural receivers (i.e., sea, } \\
\text { river, lake, etc.) over } 1.5 \% \text { can be set as a } \\
\text { reference value for VH sustainability (and/or } \\
\text { a total reduction of over15\% in comparison } \\
\text { with a reference year). These values were } \\
\text { selected taking into account the maximum } \\
\text { potential average water saving using the } \\
\text { existing technology [36] and are in } \\
\text { accordance with EN1 indicator target values } \\
\text { for the reduction of inputs/outputs. }\end{array}$ & 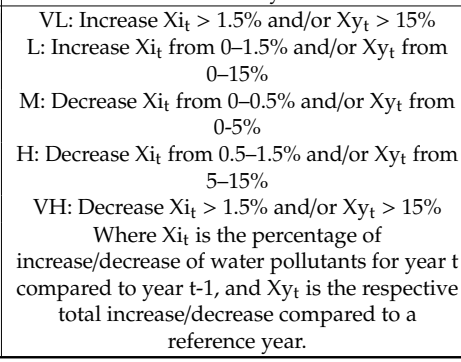 \\
\hline
\end{tabular}


Table A1. Cont.

\begin{tabular}{|c|c|c|c|}
\hline Indicator & Calculation & $\begin{array}{l}\text { Identification of a Sustainability } \\
\text { Reference Value }\end{array}$ & Normalization and Assessment \\
\hline $\begin{array}{c}\text { EN5 } \\
\text { Mining waste to be } \\
\text { deposited by type and } \\
\text { total }\end{array}$ & $\begin{array}{l}\text { Intensity of mining waste (tones/ ROM ore tones) is calculated according to the following formula: } \\
\qquad \begin{array}{l}\text { (Tailings + Waste Rock produced)- } \\
\text { (Tailings + Waste Rock waste reused) } \\
\text { Quantity of ROM ore }\end{array}\end{array}$ & $\begin{array}{l}\text { An annual reduction of mining waste } \\
\text { intensity over } 1 \% \text { can be set as a reference } \\
\text { value for VH sustainability (and/or a total } \\
\text { reduction of over } 10 \% \text { in comparison with a } \\
\text { reference year). These values were selected } \\
\text { taking into account the EU targets for the } \\
\text { efficient resource use and are in accordance } \\
\text { with EN1 indicator target values for the } \\
\text { reduction of inputs/outputs. }\end{array}$ & 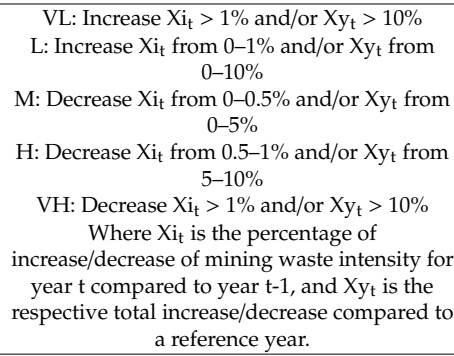 \\
\hline $\begin{array}{c}\text { EN6 } \\
\text { Energy consumption } \\
\text { by type and total }\end{array}$ & $\begin{array}{l}\text { (1) Calculation of the energy consumption of the industrial facility per type (electricity, diesel oil, etc.) and in } \\
\text { total (suggested conversion factors } 1 \mathrm{kWh} \text { electricity }=3.6 \mathrm{MJ}, 1 \mathrm{Lt} \text {. diesel = } 38.7 \mathrm{MJ}) \text {; } \\
\text { (2) Define a functional unit (tons of ROM ore is proposed); } \\
\text { (3) Calculation of energy intensity by dividing the total consumption with the selected functional unit. }\end{array}$ & $\begin{array}{l}\text { An annual reduction of energy intensity } \\
\text { over 2\% can be set as a reference value for } \\
\text { VH sustainability (and/or a total reduction } \\
\text { of over } \\
20 \% \text { in comparison with a past reference } \\
\text { year). These values were selected taking into } \\
\text { account the suggested target of the United } \\
\text { Nations Industrial Development } \\
\text { Organization [37] and are in accordance with } \\
\text { EN1 indicator target values for the reduction } \\
\text { of inputs/outputs. }\end{array}$ & 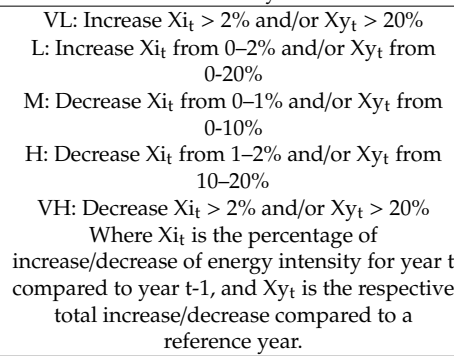 \\
\hline $\begin{array}{l}\text { EN7 } \\
\text { Total industrial water } \\
\text { consumption }\end{array}$ & $\begin{array}{l}\text { (1) Calculation of the total quantity of mine waters entering the Water Treatment Plant (WTP in); } \\
\text { (2) Deduction of the treated mine waters from the WTP discharged to natural receivers (WTP out); } \\
\text { (3) Calculation of the total water consumption in the industrial facilities, (Make up water) = (WTP in)- (WTP } \\
\text { out); } \\
\text { (4) Define a functional unit (tons of ROM ore is proposed); } \\
\text { (5) Calculation of the water use intensity by dividing the total consumption with the selected functional unit. }\end{array}$ & $\begin{array}{l}\text { An annual reduction of water use intensity } \\
\text { over } 2 \% \text { can be set as a reference value for } \\
\text { VH sustainability (and/or a total reduction of } \\
\text { over } 20 \% \text { in comparison with a past reference } \\
\text { year). These values were selected taking into } \\
\text { account the recorded water use intensity } \\
\text { reduction for several industries [38] and are } \\
\text { in accordance with EN1 indicator target } \\
\text { values for the reduction of inputs/output. }\end{array}$ & 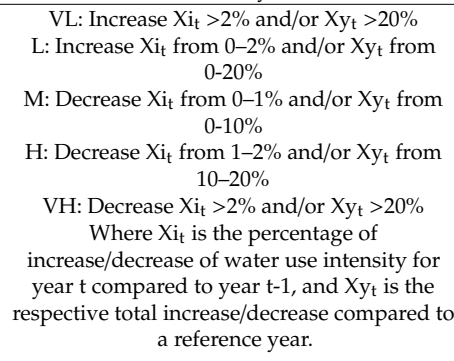 \\
\hline $\begin{array}{l}\text { EN8 } \\
\text { Percentage of water } \\
\text { that is recycled or } \\
\text { reused as compared to } \\
\text { total consumption }\end{array}$ & $\begin{array}{l}\text { Final calculation method is differentiated on a case-by-case basis and depends on the special characteristics } \\
\text { of the examined facility. For this case study the annual rainfall was taken into account whereas the water } \\
\text { inputs and outputs to the WTT during the days when treatment capability was exceeded and therefore } \\
\text { untreated mine water was discharged to the sea were not included in the estimations. }\end{array}$ & $\begin{array}{l}\text { A zero percentage of water reuse/recycling } \\
\text { can be set as a reference value for VL } \\
\text { sustainability whereas industries that } \\
\text { reuse/recycle over } 30 \% \text { of their water needs } \\
\text { are characterized by VH sustainability. }\end{array}$ & $\begin{array}{c}\mathrm{VL}: \mathrm{X}_{\mathrm{t}}=0 \\
\mathrm{~L}: 0 \%<\mathrm{X}_{\mathrm{t}} \leq 10 \% \\
\mathrm{M}: 10 \%<\mathrm{X}_{\mathrm{t}} \leq 20 \% \\
\mathrm{H}: 20 \%<\mathrm{X}_{\mathrm{t}} \leq 30 \% \\
\mathrm{VH}: \mathrm{X}_{\mathrm{t}}>30 \% \\
\text { Where } \mathrm{X}_{\mathrm{t}} \text { is the percentage of water that is } \\
\text { reused/recycled for year t. }\end{array}$ \\
\hline
\end{tabular}


Table A1. Cont.

\begin{tabular}{|c|c|c|c|}
\hline Indicator & Calculation & Identification of a Sustainability Reference Value & Normalization and Assessment \\
\hline $\begin{array}{l}\text { EN9 } \\
\text { Availability of water } \\
\text { resources at local level }\end{array}$ & $\begin{array}{l}\text { This indicator is calculated according to the Overall Water Risk for the region that can be } \\
\text { extracted from the database AQUEDUCT of the World Resources Institute (WRI) and the } \\
\text { respective interactive map (http://wwww.wri.org/our-work/project/aqueduct/aqueduct-atlas/). } \\
\text { Alternatively, water resources availability a a local level can be calculated taking into account } \\
\text { the annual rainfall (mm) for the examined year. }\end{array}$ & $\begin{array}{l}\text { A score higher than four (4) points that expresses very } \\
\text { high risk-concern regarding water resources protection in } \\
\text { the area can be set as a reference value for VL } \\
\text { sustainability (following the scale of WRI scoreboard). A } \\
\text { total annual rainfall higher than } 1,200 \mathrm{~mm} \text { can be set as a } \\
\text { reference value for VH sustainability. Normalization of } \\
\text { rainfall was conducted according to the range of average } \\
\text { rainfall in Europe (1940-1995) so as to exclude areas that } \\
\text { are characterized by extreme values (e.g. tropical forests). }\end{array}$ & $\begin{array}{c}\text { VL: } 4-5 \text { points and/or } X_{\mathrm{t}} \leq 200 \mathrm{~mm} \\
\text { L: } 3-4 \text { points and/or } 200 \mathrm{~mm}<X_{\mathrm{t}} \leq 400 \mathrm{~mm} \\
\text { M: } 2-3 \text { points and/or } 400 \mathrm{~mm}<\mathrm{X}_{\mathrm{t}} \leq 800 \mathrm{~mm} \\
\mathrm{H}: 1-2 \text { points and/or } 800 \mathrm{~mm}<\mathrm{X}_{\mathrm{t}} \leq 1,200 \mathrm{~mm} \\
\text { VH: } 0-1 \text { points and/or i } \mathrm{i}_{\mathrm{t}}>1,200 \mathrm{~mm} \\
\text { According to the results-score of the } \\
\text { AQUEDUCT database of WRI and/or in } \\
\text { combination with the regional rainfall, where } \\
X_{\mathrm{t}} \text { is the total annual rainfall for year t. }\end{array}$ \\
\hline $\begin{array}{l}\text { EN10 } \\
\text { Environmental } \\
\text { assessment of } \\
\text { suppliers and } \\
\text { contractors }\end{array}$ & $\begin{array}{l}\text { The environmental performance of suppliers and contractors of the company for the year under } \\
\text { examination is calculated with the utilization of a relevant questionnaire developed by the } \\
\text { company or an external agent. The questionnaire should cover broader issues of environmental } \\
\text { performance and should include five-scale closed type questions to facilitate implementation. }\end{array}$ & $\begin{array}{l}\text { An average score higher than } 4.5 \text { points (maximum } \\
\text { performance in all categories) can be set as a reference } \\
\text { value for VH sustainability. }\end{array}$ & $\begin{array}{c}\text { VL: } \mathrm{X}_{\mathrm{t}} \leq 1.5 \\
\mathrm{~L}: 1.5<\mathrm{X}_{\mathrm{t}} \leq 2.5 \\
\mathrm{M}: 2.5<\mathrm{X}_{\mathrm{t}} \leq 3.5 \\
\mathrm{H}: 3.5<\mathrm{X}_{\mathrm{t}} \leq 4.5 \\
\mathrm{VH}: \mathrm{X}_{\mathrm{t}}>4.5 \\
\text { Where } \mathrm{X}_{\mathrm{t}} \text { is the average score of the answers of } \\
\text { the questionnaire for year } \mathrm{t} \text {. }\end{array}$ \\
\hline $\begin{array}{l}\text { EN11 } \\
\text { Initiatives to enhance } \\
\text { environmental } \\
\text { performance, } \\
\text { accountability and } \\
\text { equity }\end{array}$ & 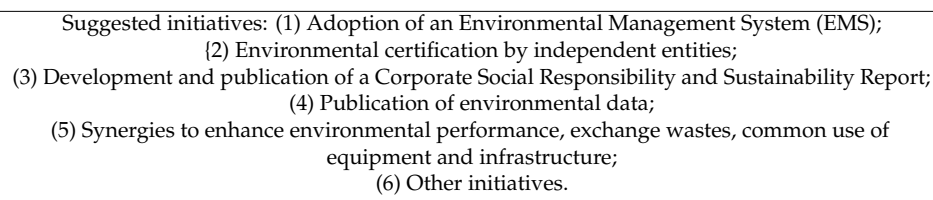 & $\begin{array}{l}\text { The adoption of at least five initiatives to enhance } \\
\text { environmental performance, accountability and equity } \\
\text { can be set as a reference value for VH sustainability. } \\
\text { Suggested initiatives were selected to reflect different } \\
\text { degree of implementation difficulty and to be } \\
\text { complementary. }\end{array}$ & $\begin{array}{l}\text { VL: At least one/zero initiative } \\
\text { L: At least two initiatives } \\
\text { M: At least three initiatives } \\
\text { H: At least four initiatives } \\
\text { VH: At least five initiatives } \\
\text { Assessment according to the number of } \\
\text { initiatives adopted during year } t \text {. }\end{array}$ \\
\hline $\begin{array}{l}\text { EN12 } \\
\text { Numbers of species } \\
\text { included in the IUCN } \\
\text { red list or national lists } \\
\text { of protected species } \\
\text { and are affected by the } \\
\text { facility's activities }\end{array}$ & $\begin{array}{l}\text { Identification and recording of the number of species included in the IUCN red list or national } \\
\text { lists of protected species and are affected by the facility's activities, classified by the level of } \\
\text { extinction risk according to relevant directives and standards. }\end{array}$ & $\begin{array}{l}\text { The operation of the facility at an environment where } \\
\text { there are only species of limited concern and as a result } \\
\text { risks from non-reversible consequences are minimized } \\
\text { can be set as a reference value for VH sustainability. }\end{array}$ & $\begin{array}{l}\text { VL: Presence of critically endangered species } \\
\text { (CR) or species of priority of Annex II of the } \\
\text { Directive } 92 / 43 / E C \text { or species of the category } \\
\text { SPEC 1* } \\
\text { L: Presence of endangered species (EN) or } \\
\text { species of Annex II and IV of the Directive } \\
\text { 92/43/EC or species of the category SPEC } 2^{*} \\
\text { M: Presence of vulnerable species (VU) or } \\
\text { species of the category SPEC } 3^{*} \\
\text { H: Presence of near threatened species (NT) } \\
\text { VH: Presence of species of limited concern } \\
\text { (LC) } \\
\text { Assessment according to the classification of } \\
\text { species per extinction risk level that are } \\
\text { affected by the facility's operation. }\end{array}$ \\
\hline
\end{tabular}


Table A1. Cont.

\begin{tabular}{|c|c|c|c|}
\hline Indicator & Calculation & $\begin{array}{l}\text { Identification of a Sustainability } \\
\text { Reference Value }\end{array}$ & Normalization and Assessment \\
\hline $\begin{array}{l}\text { EN13 } \\
\text { Identification and } \\
\text { mitigation actions on } \\
\text { biodiversity }\end{array}$ & $\begin{array}{l}\text { Suggested actions according to literature and best available techniques: } \\
\text { (1) Development of relevant observatory; } \\
\text { (2) Vulnerability study of affected species; } \\
\text { (3) Action plan for climate change and impacts on biodiversity; } \\
\text { (4) Technical works for the protection of species (e.g., fences, opening alternative roads); } \\
\text { (5) Other actions. }\end{array}$ & $\begin{array}{l}\text { A number of at least four actions to mitigate } \\
\text { the impacts of the facility's activity on } \\
\text { biodiversity can be set as a reference value } \\
\text { for VH sustainability. Suggested actions } \\
\text { were selected to reflect different degree of } \\
\text { implementation difficulty and to be } \\
\text { complementary. }\end{array}$ & $\begin{array}{l}\text { VL: No actions } \\
\text { L: At least one action } \\
\text { M: At least two actions } \\
\text { H: At least three actions } \\
\text { VH: At least four actions } \\
\text { Assessment according to the number of } \\
\text { actions/initiatives taken by the examined } \\
\text { facility during year t. }\end{array}$ \\
\hline $\begin{array}{l}\text { EN14 } \\
\text { Total area restored to } \\
\text { total disruption }\end{array}$ & $\begin{array}{l}\text { Calculation of the total area that has been restored or is under restoration expressed as a percentage of the } \\
\text { total disrupted area for the year under examination. }\end{array}$ & $\begin{array}{l}\text { The restoration of almost all the area }(95 \%) \\
\text { that has been disrupted by the company can } \\
\text { be set as a reference value for } \mathrm{VH} \\
\text { sustainability. }\end{array}$ & $\begin{array}{c}\text { VL: } X_{\mathrm{t}}<5 \% \\
\mathrm{~L}: 5 \% \leq \mathrm{X}_{\mathrm{t}}<35 \% \\
\text { M: } 35 \% \leq \mathrm{X}_{\mathrm{t}} \leq 65 \% \\
\mathrm{H}: 65 \%<\mathrm{X}_{\mathrm{t}} \leq 95 \% \\
\text { VH: } \mathrm{X}_{\mathrm{t}}>95 \% \\
\text { Where } X_{\mathrm{t}} \text { is the percentage of the total are } \\
\text { restored to the total area disrupted for year } \mathrm{t} \text {. }\end{array}$ \\
\hline $\begin{array}{c}\text { EN15 } \\
\text { Global warming } \\
\text { potential }\end{array}$ & $\begin{array}{l}\text { (1) Classification and quantification of the facility's energy consumption per energy/fuel type; } \\
\text { (2) Calculation of equivalent } \mathrm{CO}_{2} \text { emissions using national or local transformation factors per type and use. } \\
\text { The utilization of factors that take into account the fuel lifecycle is suggested; } \\
\text { (3) Sum of the results and calculation of the total } \mathrm{CO}_{2} \text { emissions due to energy consumption; } \\
\text { (4) Define a functional unit (tons of ROM ore is proposed); } \\
\text { (5) Calculation of the carbon footprint intensity by dividing the total emissions with the selected } \\
\text { functional unit. }\end{array}$ & $\begin{array}{l}\text { An annual reduction of carbon footprint } \\
\text { intensity over } 2.5 \% \text { can be set as a reference } \\
\text { value for VH sustainability (and/or a total } \\
\text { reduction of over } 20 \% \text { in comparison with a } \\
\text { past reference year). These values were } \\
\text { selected taking into account the new } \\
\text { strategic target of EU [39] for the reduction of } \\
\text { greenhouse gases emissions over } 40 \% \text { until } \\
2030 \text { (in comparison with } 1990 \text { emissions). }\end{array}$ & 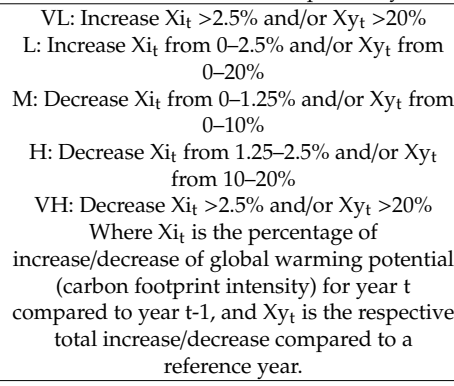 \\
\hline $\begin{array}{l}\text { EN16 } \\
\text { Number and } \\
\text { description of } \\
\text { environmental } \\
\text { accidents }\end{array}$ & $\begin{array}{l}\text { Recording of the number and detailed description of the environmental accidents occurred during the year } \\
\text { of examination. The severity and impact of the accidents must be taken into account in the evaluation. }\end{array}$ & $\begin{array}{l}\text { The complete absence of environmental } \\
\text { accidents during the year of examination can } \\
\text { be set as a reference value for VH } \\
\text { sustainability. }\end{array}$ & $\begin{array}{c}\text { VL: Extended environmental accident } \\
\text { (severe impacts) } \\
\text { L: Increase in number and/or severity of } \\
\text { environmental accidents } \\
\text { M: Decrease in number and/or severity of } \\
\text { environmental accidents } \\
\text { H: Small scale environmental accidents } \\
\text { (minimal impacts) } \\
\text { VH: Zero environmental accidents } \\
\text { (no impacts) } \\
\text { Assessment according to the number, extend } \\
\text { and severity of the environmental accidents } \\
\text { occurred compared to the previous year. }\end{array}$ \\
\hline
\end{tabular}


Table A1. Cont.

\begin{tabular}{|c|c|c|c|}
\hline Indicator & Calculation & Identification of a Sustainability Reference Value & Normalization and Assessment \\
\hline $\begin{array}{l}\text { EN17 } \\
\text { Hazard risk of utilized } \\
\text { materials, emissions } \\
\text { and waste }\end{array}$ & $\begin{array}{l}\text { (1) Utilization of the inputs/outputs list of EN1, expansion of the list, if needed, with waste and } \\
\text { emissions from EN3-EN5; } \\
\text { (2) Calculation of the contribution of every entry in the total mass balance (separate } \\
\text { inputs/outputs); } \\
\text { (3) Evaluate every entry according to its hazard risk with a grading scale of 1-3 points, where } 1 \\
\text { refers to inert material and } 3 \text { to hazardous materials. Suggested grading methods: a) Material } \\
\text { Safety Data Sheets, b) according to Scorecard guide for chemicals, c) according to other } \\
\text { regulations (i.e., SEVESO directive); } \\
\text { (4) Multiplication of the contribution of every entry with its hazard risk score and calculation of } \\
\text { the average score of all data. }\end{array}$ & $\begin{array}{l}\text { An average hazard risk score lower than } 1.5 \text { can be set } \\
\text { as a reference value for VH sustainability (the } \\
\text { majority of the inputs/outputs mass does not present a } \\
\text { critical hazard risk). }\end{array}$ & 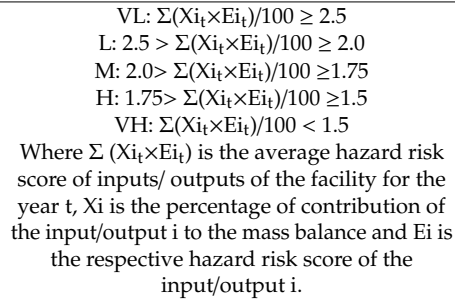 \\
\hline $\begin{array}{l}\text { EN18 } \\
\text { Ambient air quality of } \\
\text { the industrial site }\end{array}$ & $\begin{array}{l}\text { (1) Evaluation of the ambient air quality for the year under examination according to the } \\
\text { suggested gradation of the European Environment } \mathrm{Agency} \text { and the database Airbase for the } \\
\text { main air pollutants }\left(\mathrm{PM}_{10}, \mathrm{PM}_{2.5}, \mathrm{NO}_{2}, \mathrm{SO}_{2}, \mathrm{CO}\right) ; \\
\text { (2) Scoring according to the suggested limit values, } \\
\text { (3) Calculation of the average score for the five pollutants. }\end{array}$ & $\begin{array}{l}\text { An average score higher than } 4.5 \text { can be set as a } \\
\text { reference value for VH sustainability (low } \\
\text { concentrations for all pollutants). Normalization of } \\
\text { the reference values follows the suggested gradation } \\
\text { of the European Environmental Agency, in accordance } \\
\text { with the limit values for human and } \\
\text { ecosystems health. }\end{array}$ & $\begin{array}{c}\text { VL: } \mathrm{X}_{\mathrm{t}} \leq 1.5 \\
\mathrm{~L}: 1.5<\mathrm{X}_{\mathrm{t}} \leq 2.5 \\
\mathrm{M}: 2.5<\mathrm{X}_{\mathrm{t}} \leq 3.5 \\
\mathrm{H}: 3.5<\mathrm{X}_{\mathrm{t}} \leq 4.5 \\
\text { VH: } \mathrm{X}_{\mathrm{t}}>4.5 \\
\text { Where } \mathrm{Xt}_{\mathrm{t}} \text { is the average score for ambient air } \\
\text { quality for the year } \mathrm{t} \text {. }\end{array}$ \\
\hline $\begin{array}{l}\text { EN19 } \\
\text { Risk of failure of } \\
\text { infrastructure } \\
\text { (i.e. tailings dam } \\
\text { stability, underground } \\
\text { mines stability, etc.) }\end{array}$ & $\begin{array}{l}\text { (1) Assessment of the potential accidents (due to technical failure and/or human error) including } \\
\text { accidents due to natural disasters or terrorism. Large Scale Industrial Accidents are the accidents } \\
\text { that lead to large fires, explosions, leakage of toxic substances or their combination, and their } \\
\text { impacts go beyond the limits of the industrial facility; } \\
\text { (2) Estimation of the impact radius in km of the potential accidents taking into account the } \\
\text { worst-case scenario; } \\
\text { (3) Recording of inhabited areas within the impact radius and of other facilities that can worsen } \\
\text { the extent and/or the severity of the impacts (domino effect); } \\
\text { (4) Analysis of the results and short description of the preventive measures. }\end{array}$ & $\begin{array}{l}\text { The limitation of impacts within the industrial facility } \\
\text { (zero impact radius) can be set as a reference value for } \\
\text { VH sustainability. This value is attributed to } \\
\text { industrial facilities that use non-hazardous substances } \\
\text { and/or their industrial activity is of very low hazard } \\
\text { risk. On the contrary, industries whose impacts have a } \\
\text { broader scale radius are characterized by low } \\
\text { sustainability for human health. }\end{array}$ & $\begin{array}{l}\text { VL: Large scale impact radius }(>20 \mathrm{~km}) \\
\text { L: Broad scale impact radius }(1-20 \mathrm{~km})- \\
\text { inhabited areas } \\
\text { M: Broad scale impact radius }(1-20 \mathrm{~km})-\text { non } \\
\text { inhabited areas } \\
\text { H: Accidents may happen only during the } \\
\text { transfer of hazardous substances } \\
\text { VH: Accidents may happen only within the } \\
\text { industrial facility } \\
\text { According to the results of risk analysis. If } \\
\text { infrastructure is designed to withstand } \\
\text { extreme phenomena with a return period }>5 \\
\text { times their expected life cycle then the } \\
\text { performance is VH. }\end{array}$ \\
\hline
\end{tabular}




\section{References}

1. Curkovic, S.; Sroufe, R. A literature review and taxonomy of environmentally responsible manufacturing. Am. J. Ind. Bus. Manag. 2016, 6, 323-346. [CrossRef]

2. Goyal, P.; Rahman, Z.; Kazmi, A.A. Corporate sustainability performance and firm performance research. Manag. Decis. 2013, 51, 361-379. [CrossRef]

3. Barkemeyer, R.; Holt, D.; Preuss, L.; Tsang, S. What happened to the 'development' in sustainable development? Business guidelines two decades after Brundtland. Sustain. Dev. 2014, 22, 15-32. [CrossRef]

4. Maas, K.; Schaltegger, S.; Crutzen, N. Integrating corporate sustainability assessment, management accounting, control and reporting. J. Clean. Prod. 2016, 136, 237-248. [CrossRef]

5. Nicolaescu, E.; Alpopi, C.; Zaharia, C. Measuring Corporate Sustainability Performance. Sustainability 2015, 7, 851-865. [CrossRef]

6. Lopez, R.A.; Ceballos, J.D.; Montiel, I. Deconstructing corporate sustainability: a comparison of different stakeholder metrics. J. Clean. Prod. 2016, 136, 5-17. [CrossRef]

7. Bergman, M.M.; Bergman, Z.; Berger, L. An Empirical Exploration, Typology, and Definition of Corporate Sustainability. Sustainability 2017, 9, 753. [CrossRef]

8. Villeneuve, C.; Tremblay, D.; Riffon, O.; Lanmafankpotin, G.Y.; Bouchard, S. A Systemic Tool and Process for Sustainaibility Assessment. Sustainability 2017, 9, 1909. [CrossRef]

9. Moran, C.J.; Lodhia, S.; Kunz, N.C.; Huisingh, D. Sustainability in mining, minerals and energy: new processes, pathways and human interaction for cautiously optimistic future. J. Clean. Prod. 2014, 84, 1-15. [CrossRef]

10. Vintro, C.; Sanmiquel, L.; Freijo, M. Environmental sustainability in the mining sector: evidence from Catalan companies. J. Clean. Prod. 2014, 84, 155-163. [CrossRef]

11. Kazakidis, V.; Gaidajis, G.; Angelakoglou, K. Evaluation of environmental and social parameters of a gold-mining project at the prefeasibility stage: A case study. Glob. Perspect. Eng. Manag. 2013, 2, 93-104.

12. Boiral, O.; Henri, J.F. Is sustainability performance comparable? A study of GRI report of mining organizations. Bus. Soc. 2017, 56, 283-317. [CrossRef]

13. Jenkins, H.; Yakovleva, N. Corporate social responsibility in the mining industry: Exploring trends in social and environmental disclosure. J. Clean. Prod. 2006, 14, 271-284. [CrossRef]

14. Belkhir, L.; Bernard, S.; Abdelgadir, S. Does GRI reporting impact environmental sustainability? A cross-industry analysis of $\mathrm{CO}_{2}$ emissions and performance between GRI-reporting and non-reporting companies. Manag. Environ. Qual. 2017, 28, 138-155. [CrossRef]

15. Fonseca, A.; McAllister, M.L.; Fitzpatrick, P. Sustainability reporting among mining corporation: a constructive critique of the GRI approach. J. Clean. Prod. 2014, 84, 70-83. [CrossRef]

16. Tost, M.; Hitch, M.; Chandurkar, V.; Moser, P.; Feiel, S. The state of environmental sustainability considerations in mining. J. Clean. Prod. 2018, 182, 969-977. [CrossRef]

17. Gonzalez, E.D.R.S.; Sarkis, J.; Huisingh, D.; Huatuco, L.H.; Maculan, N.; Torres, J.R.M.; Almeida, C.M.V.B. Making real progress toward more sustainable societies using decision support models and tools: introduction to the special volume. J. Clean. Prod. 2015, 105, 1-13. [CrossRef]

18. Moldavska, A.; Welo, T. On the applicability of sustainability assessment tools in manufacturing. Procepedia Cirp 2015, 29, 621-626. [CrossRef]

19. Angelakoglou, K.; Gaidajis, G. A review of methods contributing to the assessment of the environmental sustainability of industrial systems. J. Clean. Prod. 2015, 108, 725-747. [CrossRef]

20. Angelakoglou, K.; Gaidajis, G. Assessing the progress of mining industry towards sustainability-In need of new methodological frameworks. In Proceedings of the 6th International Conference on Sustainable Development in the Minerals Industry-SDIMI, Milos, Greece, 30 June-3 July 2013.

21. Angelakoglou, K.; Gaidajis, G. Utilization of Industrial Ecology Principles for assessing the environmental sustainability of industries. In Proceedings of the 1st National Conference: Economics of Natural Resources and Environment-Climate Change-ENVECON, Volos, Greece, 27 March 2014.

22. Angelakoglou, K.; Gaidajis, G. Selection of indicators for assessing the environmental sustainability of industrial facilities and processes. In Proceedings of the 4th International Symposium on Green Chemistry, Health and Development, Kos Island, Greece, 24-26 September 2014. 
23. Angelakoglou, K.; Gaidajis, G. Moving from mere quantification to meaningful evaluation of environmental sustainability indicators in industry. In Proceedings of the 4th International Symposium on Green Chemistry, Health and Development, Kos Island, Greece, 24-26 September 2014.

24. Angelakoglou, K. Development of a Methodological Framework for Assessing the Environmental Sustainability of Industrial facilities and Processes. Ph.D. Thesis, Democritus University of Thrace, Xanthi, Greece, 2015. (in Greek).

25. Angelakoglou, K.; Gaidajis, G. ENSAI-index: A new methodological framework for assessing the environmental sustainability of industrial facilities. In Proceedings of the ISIE joint 12th Socio-Economic Metabolism section conference and 5th Asia-Pacific conference, Nagoya, Japan, 28-30 September 2016.

26. Gaidajis, G.; Angelakoglou, K. Sustainability of industrial facilities through water indicators. Environ. Process. 2016, 3, 91-103. [CrossRef]

27. OECD. Handbook on Constructing Composite Indicators. Methodology and User Guide. Part I. Constructing a Composite Indicator; OECD: Paris, France, 2008.

28. Pope, J.; Annandale, D.; Morrison Sanders, A. Conceptualizing sustainability assessment. Environ. Impact Assess. Revis. 2004, 24, 595-616. [CrossRef]

29. Keeble, J.J.; Topiol, S.; Berkeley, S. Using indicators to measure sustainability performance at corporate and project level. J. Bus. Ethics 2003, 44, 149-158. [CrossRef]

30. Zhou, L.; Tokos, H.; Krajnc, D.; Yang, Y. Sustainability performance evaluation in industry by composite sustainability index. Clean Technol. Environ. Policy 2012, 14, 789-803. [CrossRef]

31. Singh, R.K.; Murty, H.R.; Gupta, S.K.; Dikshit, A.K. An overview of sustainability assessment methodologies. Ecol. Indic. 2012, 15, 281-299. [CrossRef]

32. Bohringer, C.; Jochem, P.E.P. Measuring the immeasurable-A survey of sustainability indices. Ecol. Econ. 2007, 63, 1-8. [CrossRef]

33. Gasparatos, A. Embedded value systems in sustainability assessment tools and their implications. J. Environ. Manag. 2010, 91, 1613-1622. [CrossRef] [PubMed]

34. Becker, J. Making sustainable development evaluations work. Sustain. Dev. 2014, 12, 200-211. [CrossRef]

35. SPIRE. Sustainable Process Industry through Resource and Energy Efficiency. Available online: http: //www.spire2030.eu/uploads/Modules/Publications/spire-roadmap_december_2013_pbp.pdf (accessed on 25 October 2019).

36. Benito, P.; Mugdal, S.; Dias, D.; Jean-Baptiste, V.; Kong, M.A.; Inman, D.; Muro, M. Water Efficiency Standards. In Bio Intelligence Service and Cranfield University, Report for European Commission (DG Environment); Bio Intelligence Service: Paris, France, 2009.

37. UNIDO. Industrial Development Report 2011. In Industrial Energy Efficiency for Sustainable Wealth Creation; United Nations Industrial Development Organizations: Vienna, Austria, 2011; UNIDO: ID No.: 442 (2011); ISBN 978-92-1-106448-3.

38. Florke, M.; Alcamo, J. European Outlook on Water Use; Final Report (2004), EEA/RNC/03/007; Center for Environmental Systems Research, University of Kassel: Kassel, Germany, 2004.

39. European Commission, 2030 Climate and Energy Framework. Available online: https://ec.europa.eu/clima/ policies/strategies/2030_en (accessed on 25 October 2019).

(C) 2020 by the authors. Licensee MDPI, Basel, Switzerland. This article is an open access article distributed under the terms and conditions of the Creative Commons Attribution (CC BY) license (http://creativecommons.org/licenses/by/4.0/). 